\title{
PENGGUNAAN SAPAAN KEKERABATAN BAHASA MAKEAN DIALEK SAMSUMA DI DESA SAMSUMA KECAMATAN MALIFUT
}

\author{
Rini Habsi \\ Rinihabsi92@gmail.com \\ Pascasarjana Universitas Sam Ratulangi
}

\begin{abstract}
This article discusses about greeting words in Makean language in Malifut district North Halmahera regency. There are two matters in this article; first, what are the kindship greetings used in Makean language Samsuma dialect. And the second, how to use the greeting words to the family relationship in Makean language in Malifut district. The research is emphasized in sociolinguistic.

The research uses descriptive method. This research was held in Malifut district, North Halmahera regency of North Malucas Central. The technique of gathering data is listening technique and conversation technique. The family greeting words in the in the nuclear family in Samsuma dialect Makean language namely baba (faather), mama (mother), jojo (sister of mother), theno (younger sister or brother), tamno (elder brother or male cousin). The use of greeting words in the Samsuma dialect Makean language different of the Javanese language and so on because its use is not used for people who are spoken but to make or answer questions.
\end{abstract}

Keywords: Greeting words, Makean Language, Samsuma Dialect, family

\section{PENDAHULUAN}

Bahasa mempunyai peran yang besar dalam kehidupan manusia karena hampir semua aktivitas manusia berkaitan dengan bahasa. Malalui bahasa manusia dapat menjalankan aktivitasnya sebagai mahluk sosial yang tidak dapat hidup sendiri. Manusia butuh interaksi dengan sesamanya dan alat untuk berinteraksi itu disebut dengan bahasa. Pada dasarnya pembicaraan tentang bahasa todak dapat dilepaskan hubungannya dengan komunikasi, bahkan dikatakan bahwa bahasa adalah komunikasi itu sendiri. Bahasa merupakan system tanda yang paling penting dalam komunikasi.

Setiap bahasa memiliki seperangkat aturan atau kaidah. Aturan atau kaidah tersebut ada yang bersifat unik dan universal. Aturan atau kaidah bersifat unik artinya setiap bahasa mempunyai ciri khas sendiri yang tidak dimiliki oleh bahasa lainnya. Chaer dan Agustin (1995) menyatakan bahwa ciri khas bahasa bersifat unik bisa menyangkut 
sistem bunyi, sistem pembentukan kata, sistem pembentukan kalimat atau sistemsistem lainnya. Selain bersifat unik, bahasa juga bersifat universal, artinya ada cirri-ciri yang sama yang dimiliki oleh setiap bahasa di dunia ini. Aturan atau kaidah dalam bahasa yang bersifat universal meliputi kaidah di bidang fonologi, bidang morfologi, bidang sintaksis, dan bidang semantik. Aturan atau kaidah tersebut berlaku pada setiap bahasa. Aturan atau kaidah tersebut diharapkan dapat dikuasai oleh penutur bahasa secara baik.

Dalam berbahasa, setiap penutur pada hakikatnya merealisasikan sistem atau kaidah yang diketahuinya. Sejalan dengan hal ini Chomsky (dalam Tarigan, 1990) membedakan antara kompetensi dan performansi. Kompetensi merupakan pengetahuan seseorang mengenai kaidah suatu bahasa, sedangkan performansi merupakan penggunaan aktual bahasa seseorang dalam situasi-situasi nyata. Penutur bahasa diharapkan memiliki kompetensi dan performansi dalam merealisasikan kaidah suatu bahasa secara aktual dengan baik. Dengan memiliki keduanya, kegiatan komunikasi akan berjalan dengan lancar tanpa ada kesalahpahaman.

Menyinggung tentang komunikasi, bahasa merupakan sarana komunikasi antar manusia. Sarana komunikasi yang dilakukan dengan dua cara yaitu komunikasi lisan dan tulis. Komunikasi lisan adalah penyampaian pesan dari satu orang ke orang lain yang dilakukan dengan ragam bahasa lisan. Sebaliknya, komunikasi tulis adalah penyampaian pesan dari satu orang ke orang lain yang dilakukan dengan ragam bahasa tulis.

Bahasa daera bagi sebagian besar masyarakat Indonesia digunakan sebagai bahasa ibu (mother tongue) atau disebut juga Bahasa pertama (first language) yang biasa digunakan penuturnya dalam setiap keperluan baik berkomunikasi antarkelompok atau penutur Bahasa itu. Sebagai Bahasa ibu, Bahasa daerah berfungsi sebagai sarana interaksi sosial dalam lingkungan keluarga di tempat penuturnya. Dapat dikatakan bahwa Bahasa daerah juga sebagai sarana pendukung kebudayaan daerah.

Penggunaan Bahasa dalam interaksi sosial sangat beragam. Bentuk kebahasaan yang sering menyertai penggunaan bahasa lisan adalah sapaan. Variasi-variasi penggunaan bahasa ini sangat menarik untuk dipelajari dan dibahas secara ilmiah, salah satu bidang keilmuan yang membahas tentang hubungan bahasa dengan pengguna bahasanya adalah bidang sosiolinguistik. 
Sosiolinguistik didefinisikan sebagai ilmu yang membahas tentang aspek-aspek kemasyarakatan Bahasa, khususnya perbedaan-perbedaan (variasi) yang terdapat dalam Bahasa yang berkaitan dengan factor-faktor kemasyarakatan, (Nababan, 1984).

Sosiolinguistik bersasal dari kata "sosio" dan " linguistic". Sosio sama dengan kata sosial yaitu berhubungan dengan masyarakat. Linguistik adalah ilmu yang mempelajari dan membicarakan bahasa khususnya unsur- unsur bahasa dan antara unsurunsur itu. Jadi, sosiolinguistik adalah kajian yang menyusun teori- teori tentang hubungan masyarakat dengan bahasa. Berdasarkan pengertian sebelumnya, sosiolinguistik juga mempelajari dan membahas aspek-aspek kemasyarakatan bahasa khususnya perbedaan- perbedaan yang terdapat dalam bahasa yang berkaitan dengan faktor- faktor kemasyarakatan ( Nababan 1993).

Berdasarkan beberapa pendapat di atas dapat disimpulkan bahwa sosiolinguistik tidak hanya mempelajari tentang bahasa tetapi juga mempelajari tentang aspek- aspek bahasa yang digunakan oleh masyarakat.

Sosiolinguistik merupakan ilmu antardisiplin antara sosiologi dengan linguistik, dua bidang ilmu empiris yang mempunyai kaitan erat. Sosiologi merupakan kajian yang objektif dan ilmiah mengenai manusia di dalam masyarakat, lembaga- lembaga, dan proses sosial yang ada di dalam masyarakat.

Sosiologi berusaha mengetahui bagaimana masyarakat iu terjadi, berlangsung, dan tetap ada. Dengan mempelajari lembaga- lembaga, proses social dan segala masalah social di dalam masyarakat, akan diketahui cara- cara manusia menyesuaikan diri dengan lingkungannya, bagaimana mereka bersosialisasi, dan menempatkan diri dalam tempatnya masing- masing di dalam masyarakat. Sedangkan linguistik adalah bidang ilmu yang mempelajari tentang bahasa, atau ilmu yang mengambil bahasa sebagai objek kajiannya. Dengan demikian dapat dikatakan bahwa sosiolinguistik adalah bidang ilmu antardisipliner yang mempelajari bahasa dalam kaitannya dengan penggunaan bahasa itu dalam masyarakat, Chaer dan Agustina (2004). Dari uraian diatas dapat disimpulkan bahwa sosiolinguistik adalah ilmu yang mempelajari bahasa dalam kaitannya dengan bahasa yang digunakan dalam lingkungan tersebut.

Dalam ranah sosiolinguistik, Bahasa dan masyarakat sosial merupakan satu kesatuan. Belajar Bahasa atau mengamati perubahan gejala bahasa perlu memperhatikan konteks sosial tempat Bahasa itu tumbuh dan berkembang.konteks sosial yang berbeda- 
beda tentu akan memunculkan variasi bahasa yang berbeda pula. Hal ini sejalan dengan bahasa yang digunakan di pulau makean yang disebut dengan Bahasa makean. Bahasa makean mempunyai tingkatan dalam penggunaanya seperti dalam Bahasa Jawa yang dikemukakan oleh Supardo (1994), bahwa terdapat tiga tingkatan dalam Bahasa Jawa yaitu ngoko, madyo, kromo. Dalam Bahasa makean juga terdapat tiga tingkatan yaitu halus, sedang dan kasar Bowden (2001). Apabila seorang pesapa ingin menyapa seseorang yang usianya lebih tua diatas penyapa, maka bentuk sapaan yang digunakan adalah bentuk sapaan yang halus, misalnya, kata "meu" yang berarti kamu/anda, sedangkan "au" yang berarti kamu digunakan untuk sesama usia/umur dan Bahasa kasarnya biasanya disapa dengan kekurang yang ada pada orang yang disapa, misalnya, "tempang” (orang yang kakinya pencang) atau "tapengol" (orang yang telinganya tuli). Akan tetapi sapaan ini jarang digunakan karena berkesan tidak etis.

Penelitian ini tentang penggunaan bentuk kata sapaan bahasa Makean dalam interaksi sosial masyarakat penuturnya. Pendekatan kajian yang digunakan adalah pendekatan sosiolinguistik, yaitu pendekatan yang mengaitkan fenomena kebahasaan dengan aspek-aspek sosial kemasyarakatan. Mengingat karena sapaan kekerabatan mencakup pembahasan yang begit luas, penulis hanya pembatasi penulisan artikel ini pada sapaan kekerabatan bahasa Makean dialek Samsuma.

Sesuai dengan pemaparan latar belakang, berikut rumusan masalah yang disajikan dalam artikel ini.

1. Apa sajakah sapaan kekerabatan yang digunakan dalam bahasa Makean dialek samsuma?

2. Bagaimanakah penggunaan kata sapaan kekerabatan dalam bahasa Makean yang digunakan di desa Samsuma kec. Malifut?

\section{METODE PENELITIAN}

Penelitian ini merupakan penelitian sosiolinguistik. Penelitian ini menggunakan metode kualitatif, karena penelitian ini bersifat deskriptif, dan cenderung menggunakan analisis. Fishman (dalam Chaer, 2003) mengatakan kajian sosiolinguistik lebih bersifat kualitatif. Penelitian tentang bentuk kata sapaan bahasa Makean dialek Samsuma ini 
menggunakan pendekatan deskriptif. Pendekatan deskriptif adalah pendekatan yang dilakukan semata-mata hanya berdasarkan pada fakta yang ada atau fenomena yang memang secara empiris hidup pada penutur-penuturnya, sehingga yang dihasilkan atau dicatat berupa wujud bahasa seperti apa adanya. Metode yang digunakan dalam penelitian ini sebagai berikut: Metode simak adalah penjaringan data yang dilakukan dengan menyimak penggunaan bahasa (Kesuma, 2007). Dalam pelaksanaan penjaringan data, metode simak diwujudkan lewat teknik dasar dan teknik lanjutan. Teknik dasar yang digunakan adalah teknik sadap, sedangkan teknik lanjutannya adalah teknik simak libat cakap dan simak bebas libat cakap (Kesuma, 2007).

Teknik sadap adalah pelaksanaan metode simak dengan menyadap penggunaan bahasa seseorang atau beberapa orang. Penggunaan bahasa yang disadap dalam penelitian ini berbentuk lisan. Pada teknik ini peneliti menyadap tuturan warga yang dijadikan informan. Teknik simak libat cakap dilakukan dengan cara menyimak penggunaan bahasa seseorang atau beberapa orang yang dilakukan dengan ikut terlibat atau berpartisipasi (sambil menyimak), entah secara aktif atau reseptif, dalam pembicaraan (Kesuma, 2007). Dalam teknik ini peneliti terlibat langsung untuk menentukan pembentukanpembentukan dan pemunculan data. Selain itu, peneliti diakui dan disadari keberadaannya oleh lawan bicara. Teknik simak bebas libat cakap dilakukan dengan menyimak penggunaan bahasa tanpa ikut berpartisipasi dalam proses pembicaraan. Dalam teknik ini, peneliti tidak dilibatkan langsung untuk menentukan pembentukan-pembentukan dan pemunculan calon data kecuali sebagai pemerhati terhadap calon data yang terbentuk dan muncul dari peristiwa kebahasaan yang berada di luar dirinya (Sudaryanto, 1988 dalam Kesuma, 2007).

Teknik lanjutan lain yang digunakan dalam penelitian ini adalah teknik catat. Teknik catat adalah teknik menjaring data dengan mencatat hasil penyimakan tuturan masyarakat pada kartu data (Kesuma, 2007). Kemudian, metode wawancara yaitu peneliti melakukan wawancara secara langsung kepada informan. Selain itu, penulis juga merupakan penutur asli bahasa Makean dialek Samsuma sehingga sebagian data diangkat dari pengalaman sehari-hari penulis. Analisis data dalam penulisan artikel ini menggunakan kategori urutan data. Seluruh data yang tersedia dari berbagai sumber, yaitu wawancara, pengamatan yang sudah dituliskan dalam catatan lapangan, dokumen pribadi, dokumen resmi, dan sebagainya. Setelah dibaca, dipelajari, dan ditelaah, langkah berikutnya ialah mengadakan reduksi data yang dilakukan dengan jalan rangkuman yang 
inti, proses dengan pernyataan-pernyataan yang perlu dijaga sehingga tetap berada didalamnya. Langkah selanjutnya adalah menyusunnya dalam satuan-satuan. Satuansatuan itu dikategorisasikan pada langkah berikutnya. Kategori-kategorii tu dibuat sambil melakukan koding. Tahap akhir dari analisis data ini adalah mengadakan pemeriksaan keabsahan data. Setelah tahap ini mulailah kini tahap penafsiran data dalam mengolah hasil sementara menjadi teori substantif dengan menggunakan metode tertentu (Moleong, 2007).

Penyajian hasil analisis data menggunakan metode formal dan informal. Metode formal adalah perumusan analisis dengan lambang-lambang atau tanda-tanda, sedangkan metode informal adalah perumusan analisis dengan kata-kata biasa (Sudaryanto, 1993 in Hujaefa, 2011). Penyajian hasil analisis data dalam penelitian ini menggunakan metode formal dan informal. Metode formal digunakan untuk mendeskripsikan lambang-lambang sebagai transkripsi tuturan, seperti lambang “[...]" yaitu kurung siku sebagai tanda transkripsi fonetis. Metode informal yaitu perumusan dengan kata-kata biasa untuk mempermudah penulis dalam menganalisis data, dilanjutkan dengan pemaparan secara deskriptif bentuk kata sapaan bahasa Makean dialek Samsuma. Dalam penelitian ini ditetapkan bahwa informan yang dipilih sebagai narasumber harus memiliki persyaratan sebagai berikut, yaitu: 1) penutur asli bahasa Makean di kabupaten Halmahera Utara; 2) sehat jasmani dan rohani; dan 3) tidak cacat wicara. Kriteria ini ditetapkan agar data yang diberikan oleh para informan mempunyai tingkat validitas yang tinggi. Informan menjadi sumber data dalam penelitian ini.

Data merupakan bahan penelitian dan bahan yang dimaksud bukan bahan mentah melainkan bahan jadi (Sudaryanto, 1993 in Hujaefa, 2011). Sesuai dengan rumusan masalah, data penelitian ini berupa penggunaan bentuk kata sapaan yang dituturkan oleh masyarakat desa Samsuma yang berdomisili di Kecamatan Malifut kabupaten Halmahera Utara. Data ini diperoleh dari beberapa informan atau narasumber yang termasuk anggota masyarakat pengguna bahasa Makean dan bertempat tinggal di desa Samsuma. Kabupaten Halmahera Utara adalah salah satu kabupaten yang terletak di Propinsi Maluku Utara. Kabupaten ini berbatasan dengan Kabupaten Halmahera Timur dan Kabupaten Morotai Kepulauan. Penelitian ini dilaksanakan di Kecamatan Malifut, kabupaten Halmahera Utara. Pemilihan Kecamatan Malifut sebagai lokasi penelitian karena mayoritas masyarakat kecamatan Malifut khususnya desa Samsuma dalam kesehariannya masih menggunakan bahasa Makean, termasuk dalam penggunaan kata sapaan. Batas Kecamatan 
Malifut yaitu di sebelah utara berbatasan dengan Kecamatan Kao Induk, di sebelah timur berbatasan dengan Kecamatan Kao Teluk. Makean sendiri merupakan nama sebuah pulau yang terletak di kabupaten Halmahera Selatan Propinsi Maluku Utara. Bahasa Makean sendiri terdiri atas dua dialek yaitu Samsuma-Peleri dan dialek Waigiitang-Waikyon.

\section{HASIL DAN PEMBAHASAN}

Kata sapaan yang digunakan di lingkungan masyarakat Kecamatan Kedungreja, Kabupaten Malifut, Propinsi Jawa Tengah. Dalam penelitian ini berdasarkan jenis dan fungsinya yang meliputi: (a) kata sapaan dalam kekerabatan yang meliputi kata sapaan dalam hubungan kekerabatan keluarga inti dan kata sapaan dalam hubungan keluarga luas, (b) kata sapaan dalam hubungan nonkekerabatan yang meliputi kata sapaan kepada orang yang lebih tua, kata sapaan kepada orang yang lebih muda dan kata sapaan dalam jabatan atau pekerjaan. Penggunaan kata sapaan dalam hubungan kekerabatan dikelompokan menjadi 2 yakni untuk kekerabatan keluarga inti dan keluarga luas. Namun pada artikel ini penulis hanya membahas tentang keluarga inti.

\section{Kata Sapaan dalam Keluarga Inti}

\section{Baba (Ayah)}

\section{Konteks:}

Percakapan antara Bicu (A) dan Mardi (B), ketika peneliti berkunjung ke rumah mereka pada tanggal 28 JUli 2018 sekitar pukul 14.00 WIT. Percakapan menggunakan jalur bahasa lisan. Bentuk penyampaianya menggunakan bahasa Jawa yang digunakan sehari-hari, yaitu bahasa Jawa Banyumasan. Aturan yang digunakan dalam berinteraksi dilakukan sangat singkat yaitu menanyakan apakah Cecep boleh bermain atau tidak. Bicu adalah anak laki-laki berusia 11 tahun yang duduk dibangku kelas 5 Sekolah Dasar. Mardi (ayah Bicu) berusia sekitar 40 tahun berprofesi sebagai seorang petani, pembicaraan mereka sangat santai karena hanya antara anak dan ayah, namun Bicu tentunya mengungkapkannya dengan sopan terhadap ayahnya. Bicu yang baru beberapa saat pulang dari sekolah, setelah berganti baju dan makan siang mengutarakan keinginannya untuk pergi bermain ke rumah temannya (Budi) yang sehari-hari biasa bermain bersama. Kata sapaan aba sangat familiar digunakan dalam keluarga Mardi sebagai keluarga yang berlatar 
belakang keluarga di pedesaan yang bermata pencaharian sebagai petani. Berikut percakapan yang terjadi antara mereka berdua:

A: aba, la khan mamaul ado nik lomo hu, e?

[aba lak khan mamaul ado nik lomo hu, e?]

(pa, saya akan main dengan teman saya dulu, ya?)

B: ole, mhan lado tapi manganca oik, $e$.

[Ole, mhan lado tapi mayanca oik, e]

(Ya, silahkan tetapi jangan lama-lama, ya).

A: Ole. Aba, orasasa le.

[Ole. Aba, orasasa le]

(Ya Ma, hanya sebentar).

Kata sapaan aba dalam konteks percakapan di atas berasal dari kata Baba yang digunakan oleh seorang anak kepada ayahnya. Kata sapaan aba merupakan kata sapaan tidak penuh dari baba. Jadi, kata baba artinya ayah, Kata sapaan ini lumrah atau umum digunakan dalam lingkungan keluarga petani.

2. Mama (Ibu)

Konteks :

Percakapan antara Farida (A) dan Yuni (B) ketika peneliti berkunjung ke rumahnya pada tanggal 30 Juli 2018. Percakapan ini terjadi setelah beberapa saat peneliti bercakapcakap dengan Darto di ruang tamu, Farida (45 tahun) Ibunya Yuni adalah istri dari Darto. Percakapan menggunakan jalur bahasa lisan. Bentuk penyampaianya menggunakan bahasa Makean yang digunakan sehari-hari. Sekitar pukul 20.00 WIT Farida ada keperluan hendak pergi ke rumah Pak Yadi tetangga mereka. Karena situasinya cukup malam dan yang dituju agak jauh dari rumah, Farida meminta anaknya Yuni untuk menemani. Berikut percakapan yang terjadi antara ibu dan anak perempuannya itu:

A : Yun, mo mtumo mama than om Yadi loli. 
[yu, mo mtumo mama than om Yadi loli]

Yun, ayo ikut Ibu ke rumahnya omYadi).

B : Ole, ama. taban.

[Ole, ama. taban]

(Ya, Bu. Sebentar).

Kata sapaan ama merupakan kata sapaan tidak penuh dari mama dipakai seorang anak untuk memanggil orang tua perempuan. Kata Sapaan mama sebagaimana bapak biasanya dipakai oleh kalangan petani di kalangan masyarakat desa Samsuma.

3. Jojo (adik kandung dari ibu)

Konteks:

Percakapan antara Rani (A) dan Tari (B), ketika peneliti ke rumahnya pada tanggal 21 Juli 2018 sekitar pukul 07.30 WIT. Rani (28) adalah adik perempuan dari ibunya Tari (15 tahun). Percakapan menggunakan jalur bahasa lisan. Bentuk penyampaianya menggunakan bahasa makean dialek samsuma yang digunakan sehari-hari. Hari itu bertepatan dengan hari Sabtu atau hari tradisional dekat rumah Rani. Sesaat kami bercakap-cakap santai di bangku serambi, Tari menghampiri kami dengan membawa keranjang belanja karena hendak pergi ke pasar untuk belanja kebutuhan dapur. Dialog singkat pun berlangsung sebagai berikut:

A: Rani, mhan pasar li mtua pue?

[Rani, mhan pasar li mtua pue?]

Rani, kamu mau beli apa ke pasar?)

B: lak ktua tahu pasar mura li, kuki thitip pue?

[lak khan ktua tahu pasar mura li, kuki thitip pue?]

(Saya akan beli tahu di pasar murah, mau titip apa?)

A: ktitip ian ngafi kuki kpeik ikan kui. 
[ktitip ian yafi, kuki kpeik ikan kui]

(saya titip ikan teri, mau dibuat ikan kue).

Kata sapaan Jojo digunakan untuk menyapa adik dari mama atau dalam bahasa Melayu ternate jojo (mama ade), Rani adalah adik perempuan dari ibunya Tarti. Jadi, kata sapaan jojo artinya adik dari ibu kandung. Jadi, dalam konteks percakapan diatas adalah Tari akan pergi ke pasar murah kemudian adik dari ibunya (Rani) menitipkan ikan teri untuk dibuat ikan kue.

\section{4. $\quad$ Mtu (anak)}

Kata sapaan $m t u$ merupakan kata sapaan orang tua pada anak, akan tetapi pada keseluruhan etnik Makean hanya mengucapkan nama dari anak tersebut ketika menyapanya. Sapaan $m t u$ diguakan ketika menanyakan anak siapa dan akan dijawab dengan menggunakan sapaan $m t u$. Seperti pada contoh berikut.

Percakapan 1:

A: Ira, knah tahun halu lai kwam ne.

[khan tahun halu lai kwam ne.

(saya baru datang setelah pergi selama dua tahun)

B: ole, mhan nganca kuat.

[ole, mhan yanca kuat]

(iya, kamu pergi sangat lama)

A: mo ne lho ni mtu e?

[mo ne lho ni mtu e?]

B: jia lakanig mnu lalo

[itu anak sulungku]

Percakapan 2:

B: Mira, mpe nghan puja e? 
[Mira, mpe ghan puja e?]

(Mira, kamu sedang memasak apa?)

Percakapan di atas terjadi ketika seorang teman (A) dari ayah Mira (B) datang dari perantawan dan datang bertamu kei rumah Mira, percakapan (1) menggunakan sapaan $m t u$ yang merujuk pada kalimat tanya siapa bukan sapaan orang tua pada anaknya. Sedangkan percakapn (2) merupakan sapaan etnis pada umumnya yang menyapa anaknya dengan menggunakan nama dari anak itu sendiri.

\section{Bbu (cucu)}

$B b u$ merupakan sapaan untuk seorang cucu. Penggunaan kata ini sama persis seperti penggunaan kata $m t u$ yaitu hanya digunakan ketika seseorang menanyakan siapa. Sapaan seorang kakek atau nenek pada pada etnis Makean pada umumnya menggunakan nama dari anak tersebut. Seperti pada contoh percakapan berikut.

Percakapan 1.

A: Au ne lho ni bbu au e?

[au ne lho ni au e?]

(kamu ini cucunya siapa?]

B: lak e nene Aisha nidi bbu lak.

[lak e nene Aisha nidi bbu lak]

(sya cucunya nenek Aisha)

Percakapan 2.

A: Tari, mo mtumo nene than pasar li.

[Tari, mo mtumo nene than pasar li]

(Tari, Mari ikut nenek ke pasar)

Percakapn (1) terjadi ketika seorang nenek bertemu dengan sorang anak di jalan kemudian si nenek tersebut menanyakan kepada si anak tersebut dia cucunya siapa dengan 
menggunakan sapaan bbu. Sedangkan pada percakapan (2) nenek menyapa cucunya dengan memanggil nama dari cucu tersebut.

6. Tamno (kaka kandung atau sepupu laki-laki)

Sapaan tamno digunakan untuk menyapa kakak laki-laki kandung maupun sepupu laki-laki. Sapaan tamno ketika digunakan biasanya diikuti dengan nama orang yang disapa. Seperti pada $m t u$ dan $b b u$, sapaan ini juga digunakan ketika menanyakan siapa dan menjawab pertanyaan. Contoh pada percakapan berikut.

A: Anita, man isa ai nippo ja lho e?

[Anita, man is ai nippo ja lho e?]

(Anita, laki-laki yang di bawah pohon itu siapa?

B: jia lakanig tamno.

[jia lakanig tamno]

(itu kakak (laki-aki) saya)

Percakapan di atas terjadi ketika Anita dan seoran tetangga sedang duduk bersantai di halaman rumah kemudian tetangga tersebut menanyakan kepada Anita, siapa lelaki yang sedang berdiri di bawah pohon lalu Anita mejawab bahwa laki-laki tersebut adalah kakaknya.

7. Theno (adik perempuan atau laki-laki)

Theno digunakan untuk menapa adik laki-laki atau perempuan. Kata theno tiadak di gunakan secara langsung namun hanya digunakan pada kalimat tanya. Pada umumnya masyarakat etnik Makean menggunakan nama langsung untuk menyapa seorang adik atau orang yang lebih mudah dari pesapa. Berikut contoh penggunaan theno dalam percakapan sehari-hari.

percakapan 1

A: Risna, mo de than pasar li. 
[Risna, mo de than pasar li]

(Risna, ayo kita ke pasar)

B: Ole, taban.

[Ole, taban]

(iya, tunggu sebentar)

Percakapn 2

A: Rini, Risna jia lho ni theno e?

[Rini, Risna ja lho ni theno e?]

(Rini, Risna itu adiknya siapa?)

B: jia lakanig theno

[jia lakanig theno]

(dia/itu adik saya)

Percakapan (1) terjadi antara kakak beradik, di mana seorang kakak meminta kepada Risna (adik) untuk menemaninya pergi ke pasar. Pada percakapan (1) di atas kakak tidak menyapa adiknya dengan sapaan theno melainkan menyepa dengan nama adiknya tersebut. Pada percakapak (2) terjadi dialog antara tetangga dan Rini, di mana tetangga tersebut menanyakan Risna itu adik siapa. Dalam konteks ini penyapa menggunakan sapaan theno.

\section{SIMPULAN}

Dari pembahasan di atas, dapat disimpulkan bahawa sapaan kekerabatan inti pada bahasa Makean dialek Samsuma yaitu baba (papa/ayah), mama (ibu), jojo (saudara perempuan dari ibu), theno (adik perempuan atau laki-laki), tamno (kakak ksndundung atau sepupu laki-laki).

Penggunaann kata sapaa pada bahasa Makean dialek Samsuma ini berbeda dengan bahasa Jawa dan sebagainya sebab pada penggunaannya tidak digunakan untuk orang yang 
disapa melainkan untuk membuat atau menjawab pertanyaan tentang siapa (anak siapa, adik siapa, kakak siapa seperti yang tertera pada percakapan di atas.

\section{DAFTAR PUSTAKA}

Bowden, J. (2001). Taba Description of South Halmahera Language. Pacivic Linguistics. Cambera: Australian National University

Chaer, Abdul, dan Agustina, Leonie. Juni 2004. Sosiolinguistik: Perkenalan Awal. Jakarta: Rineka Cipta.

Chaer dan Agustina, 1995. Sosiolinguistik Perkenalan Awal. Jakarta: Rineka Cipta.

Crystal, David. 1991. A Dictionary of Linguistics and Phonetic. Massachusett: asil Blackwell.

Hujaefa. (2011). Sapaan Dalam Bahasa Taba di Pulau Makean. Tesis. Universitas Negeri Yogyakarta.

Kesuma, Tri Mastoyo Jati. 2007. Pengantar (Metode) Penelitian Bahasa. Yogyakarta: Carasvatibooks.

Moleong, J Lexy. 2007. Metode Penelitian Kualitatif. Bandung: PT Remaja Rosdakarya. Nababan, P.W.J (1984). Sosiolinguistik: Suatu Pengantar, Jakarta: Gramedia Sudaryanto. 1993. Metode dan Aneka Teknik Analisis Bahasa (Pengantar Penelitian. Wahana Kebudayaan Secara Linguistik). Yogyakarta: Duta Wacana University Press. 